Proc. Estonian Acad. Sci. Biol. Ecol., 2004, 53, 2, 88-105

\title{
Effect of coloured dissolved organic matter on the attenuation of photosynthetically active radiation in Lake Peipsi
}

\author{
Anu Reinart ${ }^{\mathrm{a} *}$, Birgot Paavel ${ }^{\mathrm{b}}$, and Lea Tuvikene ${ }^{\mathrm{c}}$ \\ ${ }^{a}$ Department of Limnology, Uppsala University, Norbyvägen 20, 752 36, Uppsala, Sweden \\ ${ }^{\mathrm{b}}$ Estonian Marine Institute, University of Tartu, Mäealuse 10A, 12618 Tallinn, Estonia \\ c Võrtsjärv Limnological Station, Institute of Zoology and Botany, Estonian Agricultural University, \\ 61101 Rannu, Tartumaa, Estonia
}

Received 12 March 2004, in revised form 30 March 2004

\begin{abstract}
On the basis of underwater radiation measurements and laboratory analyses of water samples, the effect of coloured dissolved organic matter (CDOM) on the light field in the largest Estonian lake, Lake Peipsi, was investigated. CDOM variation and its optical properties were compared with two other large European lakes, Vänern and Vättern in Sweden, as well as with 41 small lakes in Estonia, Sweden, and Finland. The light absorption coefficient at $380 \mathrm{~nm}$ for filtered water varied from 4.1 to $16.7 \mathrm{~m}^{-1}$ with the highest values close to the inflow of the Suur-Emajõgi River. CDOM values in L. Peipsi are in the same range as measured earlier in small Estonian and Finnish lakes. Various optical water types ("brown", "moderate", "turbid") were sampled over L. Peipsi. It is shown that the use of GF/F filters results in on average $4 \%$ higher absorption values than the use of filters with pore size $0.2 \mu \mathrm{m}$, and the effect might be up to $\pm 20 \%$ in clear waters. Comparison of spectral measurements of diffuse attenuation coefficient with three-band spectrometer's data showed high consistence of datasets. This allows supplementing the existing database of optical properties of lakes in Estonia with new data from L. Peipsi.
\end{abstract}

Key words: light field, optical properties, dissolved organic matter.

\section{INTRODUCTION}

Lake Peipsi on the border of Estonia and Russia is a large northern lake, unique in its nature - shallow, eutrophic, biologically very productive, and bordered by many wetland areas along its coast. About 240 rivers and streams fall into L. Peipsi

*Corresponding author, anu.reinart@ebc.uu.se 
and there is only one outflow, the Narva River, carrying the water from L. Peipsi to the Gulf of Finland (Nõges, 2001).

The underwater light field determines components of ecological conditions in water: primary production (Krause-Jensen \& Sand-Jensen, 1998), species composition of the phytoplankton communities (Schanz, 1985), depth distribution of submerged macrophytes (Duarte, 1991), and heat budget of the water body (Fedorov \& Ginsburg, 1992).

The diffuse attenuation coefficient, $\left(K_{\mathrm{d}}\right)$, characterizes the gradient of the vertical decrease of irradiance in the water. It depends on surface and illumination conditions, but also on concentrations of optically active substances (OAS) in water (Dera, 1992). This parameter is widely used in practice to characterize the light field and propagation of photosynthetically active radiation (PAR, spectral range $400-700 \mathrm{~nm}$ ) inside water, because it is rather easily determined by standard and commercially available instruments, and also closely related to inherent optical properties of water (Kirk, 1994; Mobley, 1994). The water in Lake Peipsi is rich in all OAS: phytoplankton, suspended mineral particles, and dissolved organic matter (DOM).

In natural water bodies DOM is not identifiable as a distinct molecule, but it is a rather indeterminate mixture of dissolved organic substances (Dera, 1992). Its chromophore-containing compounds contribute significantly to the total light absorption in the water. These OAS are mostly referred to as coloured dissolved organic matter (Hoge et al., 1993; Kallio, 1999) or chromophoric dissolved organic matter, CDOM (Miller et al., 2000). In northern inland waters DOM is an important variable of the water ecosystem as it affects the water colour and quality, it captures energy that could be available for photosynthesis, and influences photochemical mineralization of dissolved organic carbon (Davies-Colley \& Vant, 1987; Jansson, 1998; Kallio, 1999). Concentrations of DOM are especially high in boreal and northern lakes, where it is transported to lakes from soil leaching and surface water runoff (mainly rivers). The lakes influenced by high amounts of DOM develop carbon dioxide supersaturation of the water and export of carbon dioxide to the atmosphere (Cole et al., 1994; Sobek et al., 2003). Released carbon dioxide on the other hand has an effect for climate change (Freeman et al., 2001). The concentration of DOM in freshwater environments has implications for the further transport to the marine environment and therefore has a significant influence on coastal ecosystems.

CDOM (also called yellow substance and gilvin) refers to any type of DOM, regardless of its origin, which has optical effect (Bricaud et al., 1981) and can be measured by optical methods (Lindell et al., 1999). Its amount in water is commonly expressed as the absorption coefficient of filtered water at some fixed wavelength and a parameter describing spectral variation (Davies-Colley \& Vant, 1987; Dera, 1992; Gege, 2000).

We investigated the effect of CDOM on the light field in Lake Peipsi, relying on the data obtained in the course of field measurements of downwelling and 
upwelling irradiances, as well as by laboratory analyses of water samples. For comparison analogous data from two other large European lakes (Vänern and Vättern in Sweden) and numerous small lakes and coastal waters in Estonia and Finland were used. As the datasets were collected using different instruments and different methods, special attention was paid to comparative analyses.

\section{MATERIALS AND METHODS}

Field campaigns to measure optical properties were carried out on 11-18 and 26 June, 18 Aug, and 4 Nov 2003 in Lake Peipsi s.s. and in narrow Lake Lämmijärv (Fig. 1). As the third basin of Lake Peipsi - Lake Pihkva (Pskov) - belongs almost entirely to Russia it was not visited by us in 2003.

Underwater irradiance measurements were made using two instruments. One of them was a GER 1500 (capable of measuring in the upward and downward directions, spectral range $400-900 \mathrm{~nm}$, resolution $2 \mathrm{~nm}$ ) mounted into a waterproof box. The measurements setup was the same as used in deep Swedish lakes (Strömbeck, 2001). The vertical diffuse attenuation coefficient, $K_{\mathrm{d}}(\lambda)$, can be

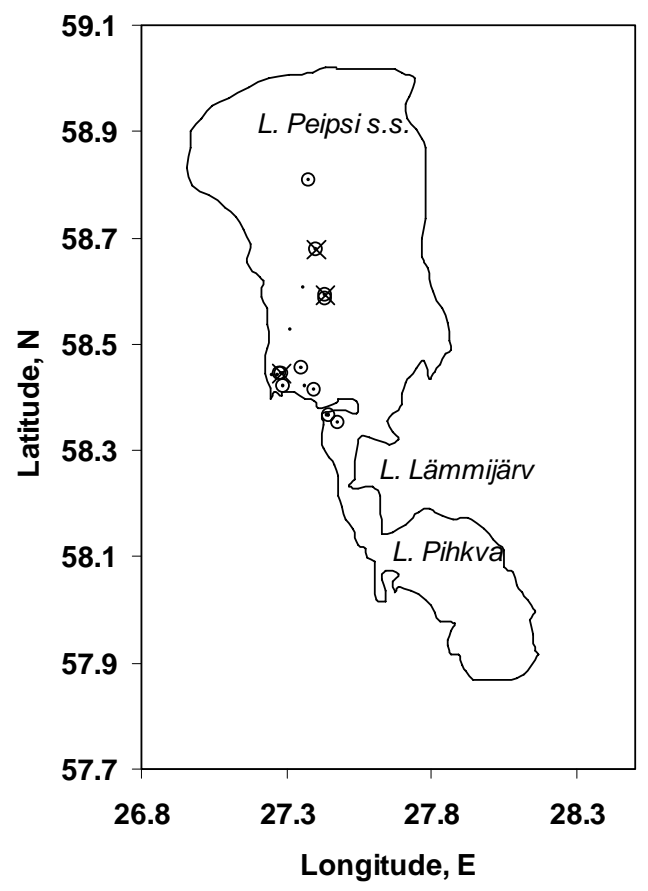

Fig. 1. Scheme of L. Peipsi with measurement sites during the field campaign in 2003: dots show points for water samples, circles for radiation measurements, and crosses for spectral measurements. 
calculated for the depth interval from the measured irradiances at two different depths $\left(z_{1}\right.$ and $\left.z_{2}\right)$ using the equation:

$$
K_{\mathrm{d}}(\lambda)=-\frac{1}{z_{2}-z_{1}} \ln \left[\frac{E_{\mathrm{d}}\left(\lambda, z_{2}\right)}{E_{\mathrm{d}}\left(\lambda, z_{1}\right)}\right],
$$

where $E_{\mathrm{d}}\left(\lambda, z_{1}\right)$ and $E_{\mathrm{d}}\left(\lambda, z_{2}\right)$ are the values of irradiances at depths $z_{1}$ and $z_{2}$. During our field trips it was possible to use this instrument setup only in the deepest places (7-9 m) in the centre of L. Peipsi s.s. (Fig. 1; 3 measurements), as a special ship was needed to lower the frame with all instruments (Reinart et al., 2004).

Another instrument that we used for measuring underwater irradiance was a profiling radiometer BIC-2104 (Biospherical Instruments Inc.) with three bands $\left(412,555,665 \mathrm{~nm}\right.$ ), a PAR sensor (units $\mu$ Einsteins $\mathrm{m}^{-2} \mathrm{~s}^{-1}$ ), and an additional surface PAR sensor. This instrument is easy to handle and suitable for measurements even in very shallow water (at least $\sim 20 \mathrm{~cm}$ ). Data were collected continuously during lowering and lifting the instrument and stored together with the respective depth (precision $\pm 2 \mathrm{~cm}$ ) and temperature data into a laptop computer. Immediately after vertical profiling dark current values were also measured during $5 \mathrm{~s}$ and subtracted from data according to the measurement instructions provided by the producer. Irradiance data were corrected for changes in incident light according to Virta \& Blanco-Sequeiros (1995). The depth-averaged values of $K_{\mathrm{d}}(\lambda)$ and $K_{\mathrm{d}, \mathrm{PAR}}$ (respectively spectral and PAR diffuse attenuation coefficients) were determined in the following way: irradiance values down to the depth where the value is $1 \%$ of the subsurface value were fitted by least-squares to a straight line on a semilog plot, the slope of which is determined by $K_{\mathrm{d}}$. The determination coefficient of logarithmic fit was always higher than 0.97. The measurements with the BIC-2104 were made in 11 points in L. Peipsi (Fig. 1).

The effect of a dark current on the value of $K_{\mathrm{d}}$ was investigated separately. Application of a dark current correction yielded 12.7-37.2\% higher $K_{\mathrm{d}}$ in the $412 \mathrm{~nm}$ band; the effect in other channels was much lower, being -2.6 to $+0.4 \%$ in the $555 \mathrm{~nm}$ band and -2.8 to $+0.2 \%$ in the $665 \mathrm{~nm}$ band. The corrected and uncorrected results differed by -17.4 to $+0.4 \%$ in the PAR band. The differences were highest in the case of low values of irradiance (cloudy day and/or late time of day).

Water samples (16) were collected only from the surface layer $(0.2 \mathrm{~m})$. A standard water sampler was used and the samples were stored in dark and cold for less than $7 \mathrm{~h}$ before filtering. The relative transparency of water was measured using Secchi disc during the time of sampling. For chlorophyll concentrations $\left(C_{\text {chl }}\right)$ 0.5-1.0 L of water was filtered through Whatman $\mathrm{GF} / \mathrm{F}$ filters (pore size $0.6-0.7 \mu \mathrm{m}$ ). The chlorophyll $a+$ phaephytin $a$ concentration was measured spectrophotometrically on ethanol extracts of filters according to the ISO 10260 standard method (Lindell et al., 1999). The concentration of suspended matter, $C_{\mathrm{SM}}$, was measured gravimetrically after filtration of the same amount of water through 
pre-weighed and pre-combusted Whatman GF/F filters; the inorganic fraction, $C_{\mathrm{SIM}}$, was measured after combustion at $550^{\circ} \mathrm{C}$ for $30 \mathrm{~min}$.

The light absorption coefficient of filtered water was measured spectrophotometrically using a PERKIN ELMER Lambda 40 UV/VIS spectrometer (in the range $300-900 \mathrm{~nm}$ ) in a $10 \mathrm{~cm}$ cuvette as the difference between the sample and distilled water, the result is denoted as $c_{f}^{*}$. The values of the absorption coefficient for yellow substance, $a_{\mathrm{ys}}$, can be estimated in the following way (Bricaud et al., 1981):

$$
a_{\mathrm{ys}}(\lambda)=c_{f}^{*}(\lambda)-\beta(\lambda),
$$

where $\beta(\lambda)$ is the correction for residual scattering:

$$
\beta(\lambda)=c_{f}^{*}\left(\lambda_{\mathrm{R}}\right)\left(\lambda_{\mathrm{R}} / \lambda\right)^{g} .
$$

Usually $\lambda_{\mathrm{R}}$ is taken equal to $750 \mathrm{~nm}$, but for the parameter $g$ the values 0,1 , and 2 have been proposed (Bricaud et al., 1981; Davies-Colley \& Vant, 1987; Gallie, 1994; Mäekivi \& Arst, 1996; Kallio, 1999; Aas, 2000; Sipelgas et al., 2003). In the present study we use the values $\lambda_{\mathrm{R}}=750 \mathrm{~nm}$ and $g=1$. The absorption spectra were approximated by a linear regression between the logarithm of $a_{\mathrm{ys}}(\lambda)$ and the wavelengths between 380 and $550 \mathrm{~nm}$ (e.g. Bricaud et al., 1981):

$$
a_{\mathrm{ys}}(\lambda)=a_{\mathrm{ys}}\left(\lambda_{0}\right) e^{-S\left(\lambda-\lambda_{0}\right)},
$$

where $a_{\mathrm{ys}}\left(\lambda_{0}\right)$ is the absorption coefficient (in $\mathrm{m}^{-1}$ ) at reference wavelength $\lambda_{0}$ (in $\mathrm{nm}$ ), and $S$ is the slope factor of the spectrum. We calculated the factor $S$ over the spectral range $380-550 \mathrm{~nm}$ and took $\lambda_{0}=420 \mathrm{~nm}$ as suitable for parameterization of the simple bio-optical model elaborated by Pierson \& Strömbeck (2001). For comparison with other studies in Estonian lakes made by Arst et al. (1999), Sipelgas et al. (2003), and Reinart et al. (2003), $a_{\mathrm{ys}}$ values at both 420 and $380 \mathrm{~nm}$ are used in the present study.

We made repeated measurements using Whatman GF/F (pore size $0.6-0.7 \mu \mathrm{m}$ ) and Whatman polyethersulfone filters (pore size $0.2 \mu \mathrm{m}$ ), as in many previous studies elsewhere and especially in Swedish, Estonian, and Finnish lakes (Mäekivi \& Arst, 1996; Östlund et al., 2001; Strömbeck \& Pierson, 2001; Sipelgas et al., 2003 ) filters with different pore size were used. Additionally to 16 L. Peipsi water samples, we analysed water samples collected from 20 southern Swedish lakes (26 June to 7 July 2003), 6 southern Estonian lakes (11-13 June 2003), 15 southern Finnish lakes (9-19 June 2002), 12 samples from L. Vättern (29-31 May 2002), and 21 samples from L. Vänern (21-23 May 2002). Data on OAS in all investigated water bodies (102 samples in total) are shown in Table 1. Samples from L. Vänern were filtered first through GF/F filters and only after two months analyses were repeated for $0.2 \mu \mathrm{m}$ filters. 
Table 1. Mean values and respective standard deviations for some bio-optical parameters in lake waters obtained during measurement campaigns in 2002-03

\begin{tabular}{l|c|c|c|c|c|c}
\hline & $\begin{array}{c}C_{\mathrm{chl}}, \\
\mathrm{mg} \mathrm{m}^{-3}\end{array}$ & $\begin{array}{c}C_{\mathrm{SM}}, \\
\mathrm{g} \mathrm{m}^{-3}\end{array}$ & $\begin{array}{c}C_{\text {SIM }}, \\
\mathrm{g} \mathrm{m}^{-3}\end{array}$ & $\begin{array}{c}a_{\mathrm{ys}}(380), \\
\mathrm{m}^{-1}\end{array}$ & $S(380-550)$ & $\begin{array}{c}\text { Secchi } \\
\text { depth, } \\
\mathrm{m}\end{array}$ \\
\hline L. Peipsi & $12.7 \pm 14.8$ & $9.5 \pm 7.5$ & $4.9 \pm 4.1$ & $6.93 \pm 3.95$ & $0.018 \pm 0.001$ & $1.7 \pm 0.9$ \\
Estonian lakes* & $21.1 \pm 20.1$ & $6.3 \pm 5.9$ & $1.2 \pm 1.5$ & $4.92 \pm 3.22$ & $0.016 \pm 0.002$ & $2.7 \pm 1.8$ \\
L. Vänern & $3.6 \pm 1.5$ & $1.2 \pm 0.4$ & $0.4 \pm 0.3$ & $3.63 \pm 1.31$ & $0.014 \pm 0.002$ & $4.0 \pm 0.6$ \\
L. Vättern & $1.8 \pm 0.6$ & $0.6 \pm 0.2$ & $0.1 \pm 0.1$ & $0.95 \pm 0.21$ & $0.014 \pm 0.002$ & $9.1 \pm 0.4$ \\
Finnish lakes* & $13.7 \pm 14.2$ & $5.9 \pm 7.3$ & $0.3 \pm 0.2$ & $7.80 \pm 4.26$ & $0.016 \pm 0.004$ & $2.4 \pm 1.6$ \\
Small Swedish lakes & $2.18 \pm 2.98$ & $3.0 \pm 2.6$ & $1.1 \pm 2.0$ & $12.03 \pm 7.60$ & $0.015 \pm 0.001$ & $2.32 \pm 1.26$
\end{tabular}

* Data from small lakes database (1994-2000) are included.

For comparison of the results obtained for L. Peipsi with other lakes, we used the database of small Estonian and Finnish lakes collected by the marine optics workgroup, Estonian Marine Institute, in cooperation with the Department of Geophysics, University of Helsinki, during the years 1994-2000 (published partly by Reinart \& Herlevi, 1999; Arst, 2003; Reinart et al., 2003). We processed raw data to get values of $K_{\mathrm{d}}(\lambda)$ from underwater irradiance measurements with a spectroradiometer LI-1800 UW. LI-1800 UW measures in the range $300-850 \mathrm{~nm}$, with a resolution of $2 \mathrm{~nm}\left(\mathrm{~W} \mathrm{~m}^{-2} \mathrm{~nm}^{-1}\right)$, at depths $0.5-6 \mathrm{~m}$, depending on water properties and light conditions. Changes in underwater irradiance due to variation of incident irradiance (time, cloud cover) were taken into account using simultaneously recorded air pyranometer data. From these spectra the averaged over depth attenuation coefficient and integral over PAR region $\left(K_{\mathrm{d}, \mathrm{PAR}}\right)$ were estimated also by logarithmic fit irradiance $v s$. depth data. Mostly the values of $K_{\mathrm{d}}$ for the 0.5-2 m layer were used. Data with exceptionally high (or low) values were excluded as these contained more errors and noise. All together 84 spectra $(400-800 \mathrm{~nm})$ were analysed. This database includes also values for OAS, which are shown together with our samples in Table 1.

\section{RESULTS AND DISCUSSION}

\section{Absorption by yellow substance}

Over L. Peipsi 16 points were sampled at different distances from the mouth of the Suur-Emajõgi River towards the open area of the lake $(0.5-15 \mathrm{~km})$, in the shallow area around Piirissaare Island, and in L. Lämmijärv. The values of $a_{\mathrm{ys}}(380)$ for samples that were taken at least $2.9 \mathrm{~km}$ from the shore were lower (4.1-5.7 $\mathrm{m}^{-1}$ ), being therefore slightly lower than the average for many Estonian and Finnish lakes $\left(6.6 \mathrm{~m}^{-1}\right)$ estimated earlier by Sipelgas et al. (2003). The 
concentration of CDOM in the water of L. Vänern was close to the lowest limit of L. Peipsi, while L. Vättern had a really low absorption by CDOM (Table 1). As can be expected, the highest value of $a_{\mathrm{ys}}(380)$ in L. Peipsi was measured in the point closest to the Suur-Emajõgi River mouth (Fig. 2, at $634 \mathrm{~m}$ ). The other points in Fig. 2 with high values of $a_{\mathrm{ys}}(380)$ were sampled up to $12 \mathrm{~km}$ from the river mouth but close to the shore or Piirissaare Island.

There is no systematic variation in the slope parameter $S(380-550)$ estimated from samples. It varies from 0.015 to $0.019 \mathrm{~nm}^{-1}$ and is in the same range as reported before for Estonian lakes (Arst, 2003; Sipelgas et al., 2003). In L. Vänern and L. Vättern $S(380-550)$ values are slightly lower, but there is also rather large variability among samples. For L. Vättern the average value reported earlier is much higher $\left(0.017 \mathrm{~nm}^{-1}\right.$ by Strömbeck, 2001) than the value estimated by our latest measurements (Table 1) using the same method. However, in L. Vättern there was also large variation over a limited number of samples (15 samples and the range of $S(380-550)$ was $0.009-0.033 \mathrm{~nm}^{-1}$, by N. Strömbeck, 2004, pers. comm.). In L. Peipsi the lowest value of $S(380-550)$ was measured in the closest point to the shore (Fig. 2); however, by this one point we cannot conclude that there is really variation in the types of DOM. In natural waters large variation of $S$ values from 0.004 up to $0.053 \mathrm{~nm}^{-1}$ over seasons, locations, and water types have been reported (overview in Aas, 2000).

A rather thorough investigation on the optical properties of DOM was carried out by Sipelgas et al. (2003). The measurement data in the period 1994-99 for 13 Estonian and 11 Finnish small lakes (altogether 462 spectra) were used. The mathematical approximation of $a_{\mathrm{ys}}(\lambda)$ spectra as well as the values of slope factor were studied. The respective range of $S$ for Estonian lakes (different spectral intervals and different values of $g$ ) was 0.006-0.030 (Sipelgas et al., 2003).

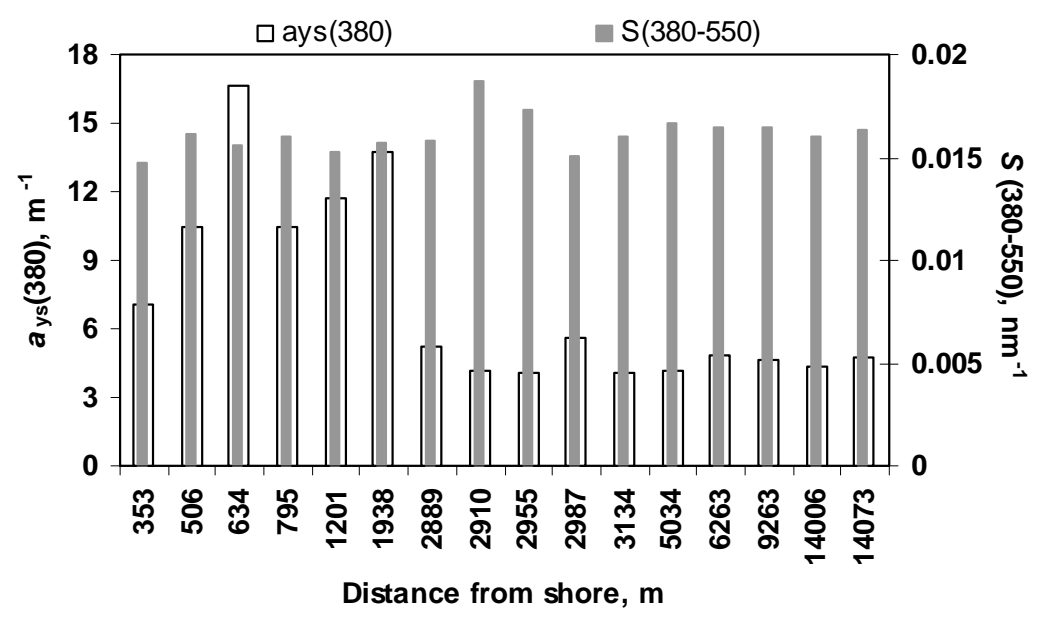

Fig. 2. Variation of $a_{\mathrm{ys}}(380)$ and $S(380-550)$ in L. Peipsi obtained by measurements in 2003. 
Some authors note a general trend of the shape factor to increase with decreasing yellow substance absorption in a large range of lakes and sea areas (Davies-Colley \& Vant, 1987; Aas, 2000). Rather often the slope factor is high in lakes where the amount of yellow substance is large (Herlevi et al., 1999; Arst, 2003); this is also the case in L. Peipsi $\left(0.0176 \mathrm{~nm}^{-1}\right.$ compared with $0.0144 \mathrm{~nm}^{-1}$ in L. Vänern; Table 1). This variation may be caused by different organic compounds forming yellow substance (Kallio, 1999; Miller et al., 2000). As shown by Sipelgas et al. (2003), the slope factor is very much affected by the spectral range for which it is calculated. The slope parameter may be $\sim 30 \%$ lower when calculated over the spectral range $350-700 \mathrm{~nm}$ compared with the range $350-500 \mathrm{~nm}$ as attenuation at longer wavelengths is generally small. Correction for residual scattering also increases $S$ values by 10-20\% depending on the correction type (parameter $g$ may be 0,1 , or 2 ).

Analyses of the effect of the pore size of the filter on the absorption coefficient showed a very good correlation between data from GF/F (pore size 0.6-0.7 $\mu \mathrm{m}$ ) and $0.2 \mu \mathrm{m}$ filters (Fig. 3). The values estimated using GF/F filters were on average $4 \%$ larger than those obtained using filters with the small pore size; however, the correlation coefficient was very high $\left(R^{2}>0.99\right)$ between the two datasets (Fig. 3a). Differences in absorption values are larger in waters whose $a_{\mathrm{ys}}(380)$ values are less than $2.5 \mathrm{~m}^{-1}( \pm 20 \%)$ because of measurement errors. In clearwater lakes $a_{\mathrm{ys}}(380)$ may be even higher after the second filtering as micro bubbles cause additional scattering (Gege, 2000). In turbid waters $a_{\mathrm{ys}}(380)$ values are lower when smaller pore size is used as more particles are removed from the water. The difference is less than $4 \%$ when $a_{\mathrm{ys}}(380)$ is higher than $8 \mathrm{~m}^{-1}$. The two months' delay in the second filtering analyses (L. Vänern data) brought about more scattered results; however, they are still close to other data. A decrease
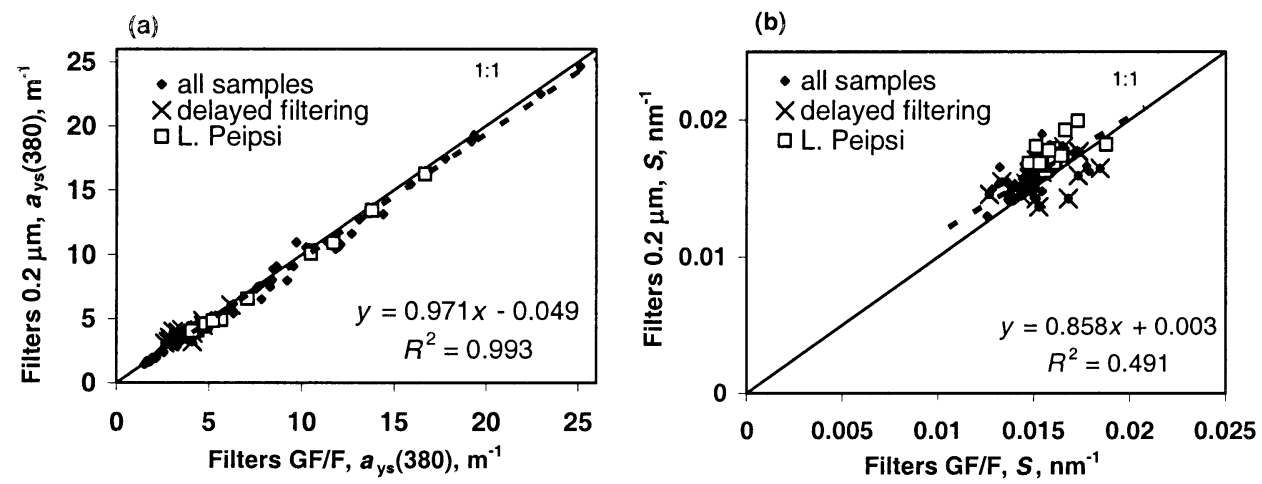

Fig. 3. Comparison of results obtained using filters with pore size $0.6-0.7 \mu \mathrm{m}$ and $0.20 \mu \mathrm{m}$ : (a) absorption coefficient at $420 \mathrm{~nm}$ and (b) slope parameter $S(380-550)$ in lakes in Sweden, Finland, and Estonia. Samples for which filtering was delayed are not included into calculation. 
in $a_{\mathrm{ys}}(380)$ values after filtering samples through $0.2 \mu \mathrm{m}$ pore filters was also found in a few samples from eutrophic lakes (Sipelgas et al., 2003).

The slope parameter values estimated from both datasets (GF/F and $0.2 \mu \mathrm{m}$ ) vary more irregularly (Fig. 3b). Analyses with smaller pore size filters gave a higher slope (in L. Peipsi 0.0176 \pm 0.0009 ) compared with larger pore size analyses (in L. Peipsi $0.0162 \pm 0.0007$ ). Again, samples that were analysed later differed more from the other samples (standard deviation 0.002), probably because some colloidal material was formed.

The small negative intercept value in the relationship between absorption values (Fig. 3a) and the positive intercept in the relationship between slope values (Fig. 3b) indicate that some small particles had really remained in water after filtering through a $\mathrm{GF} / \mathrm{F}$ filter and that these were removed by second filtering.

Bio-optical models by different authors use different wavelengths to parameterize yellow substance absorption. In this study we compared the results obtained for wavelengths 420 and $380 \mathrm{~nm}$. There are very good linear relationships between the absorptions measured at 420 and $380 \mathrm{~nm}$. The relevant parameters are listed in Table 2 (only GF/F filter results are shown). The correlation coefficient obtained using Eq. 4 and slope parameters calculated from measured spectra was also very high. The respective standard error was $0.08 \mathrm{~m}^{-1}$. When a constant slope factor is applied $\left(0.00154 \mathrm{~nm}^{-1}\right.$ as average over the whole dataset), correlation will still remain high and the relative error of the estimate is the same as when the empirical linear relationship is used $\left(0.13 \mathrm{~m}^{-1}\right)$. This suggests that a slope value as close as possible to the value for the water body under investigation should be used in bio-optical models. However, variation in measurements still causes an error around $10 \%$ in the estimated values of $a_{\mathrm{ys}}(420)$.

The suitability of the exponential function for modelling the yellow substance absorption coefficient in L. Peipsi was estimated by calculating the relative differences between the measured and the modelled (Eq. 4) spectra using the average slope value $0.0162( \pm 0.0007) \mathrm{nm}^{-1}$, and also the slope values calculated from every single measured spectrum. In the blue region of the spectrum both results are very close to the measured values - average $S$ results in a larger standard deviation among results, but the error does not exceed 1\% (Fig. 4). In other spectral regions differences are larger (around 20\%) and the use of average $S$ increases the standard deviation among samples up to $42 \%$. In general, the exponential

Table 2. Parameters for linear regression between measured $(Y)$ and calculated $(X) a_{\mathrm{ys}}(420)$ values $(N=102)$

\begin{tabular}{ll|l|l}
\hline \multicolumn{1}{c|}{$X$} & \multicolumn{1}{c|}{ Relationship } & \multicolumn{1}{c|}{$R^{2}$} & $\mathrm{SE}$ \\
\hline$a_{\mathrm{ys}}(380)$ measured & $Y=0.499( \pm 0.002) X-0.087( \pm 0.023)$ & 0.998 & 0.13 \\
$a_{\mathrm{ys}}(420)=a_{\mathrm{ys}}(380) \exp (-S \times 40)$ & $Y=0.880( \pm 0.003) X$ & 0.999 & 0.08 \\
$a_{\mathrm{ys}}(420)=a_{\mathrm{ys}}(380) \exp (-0.0152 \times 40)$ & $Y=0.918( \pm 0.005) X-0.087( \pm 0.023)$ & 0.997 & 0.13
\end{tabular}




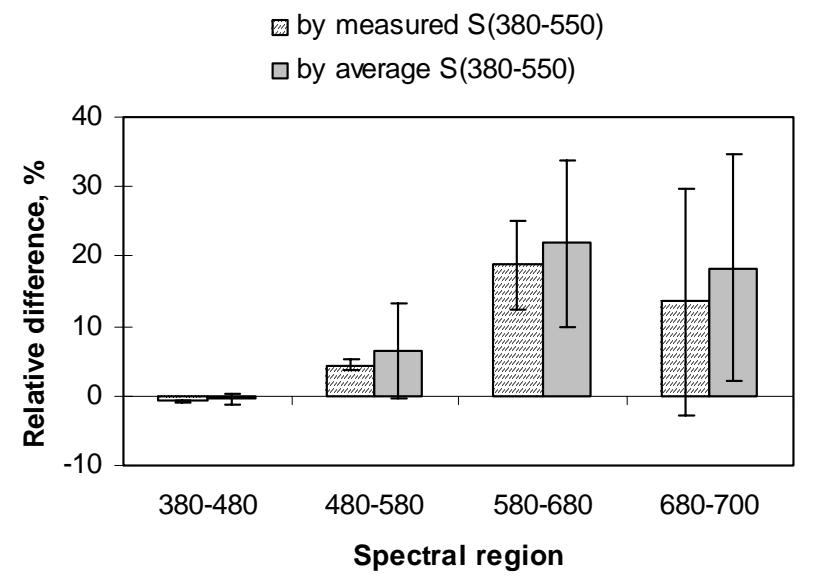

Fig. 4. Comparison of values of relative differences $\left[a_{\mathrm{ys}}\right.$ (meas) $-a_{\mathrm{ys}}$ (calc) $] / a_{\mathrm{ys}}$ (meas) using the average slope $S(380-550)$ and estimated from each sample of L. Peipsi. Boxes show the average value and vertical lines the standard deviation of samples.

model gives slightly higher values of absorption in the region $380-480 \mathrm{~nm}$, but in other spectral regions the values are underestimated by up to $40 \%$. When $\lambda>700 \mathrm{~nm}$, errors may increase many times, as absolute values become very low in all L. Peipsi samples.

Analysing 462 filtered water samples from different lakes, Sipelgas et al. (2003) showed that the smallest difference between modelled and measured spectra is achieved when the slope parameter is calculated over a narrow wavelength interval (380-500 instead of 350-700 nm) despite the scattering correction method. For models over the whole PAR 350-700 region it causes underestimation of absorption in the red region of the spectrum by around $\pm 40 \%$, which is very similar to our results for L. Peipsi spectra. As total absorption in the red region is high because of absorption of light by water itself, the produced errors may be considered insignificant except for waters with high concentrations of CDOM where $a_{\mathrm{ys}}(380)>6.3 \mathrm{~m}^{-1}$. Then $a_{\mathrm{ys}}(600)$ becomes higher than absorption by water at this wavelength, $0.2224 \mathrm{~m}^{-1}$ (Pope \& Fry, 1997). Therefore these errors will be significant in bio-optical modelling of L. Peipsi coastal waters.

\section{Spectral diffuse attenuation coefficient}

All optically active components affect irradiance attenuation in water in a different manner, therefore the absolute values and shape of $K_{\mathrm{d}}$ spectra may differ significantly (Fig. 5). In L. Peipsi the spectral diffuse attenuation coefficient 

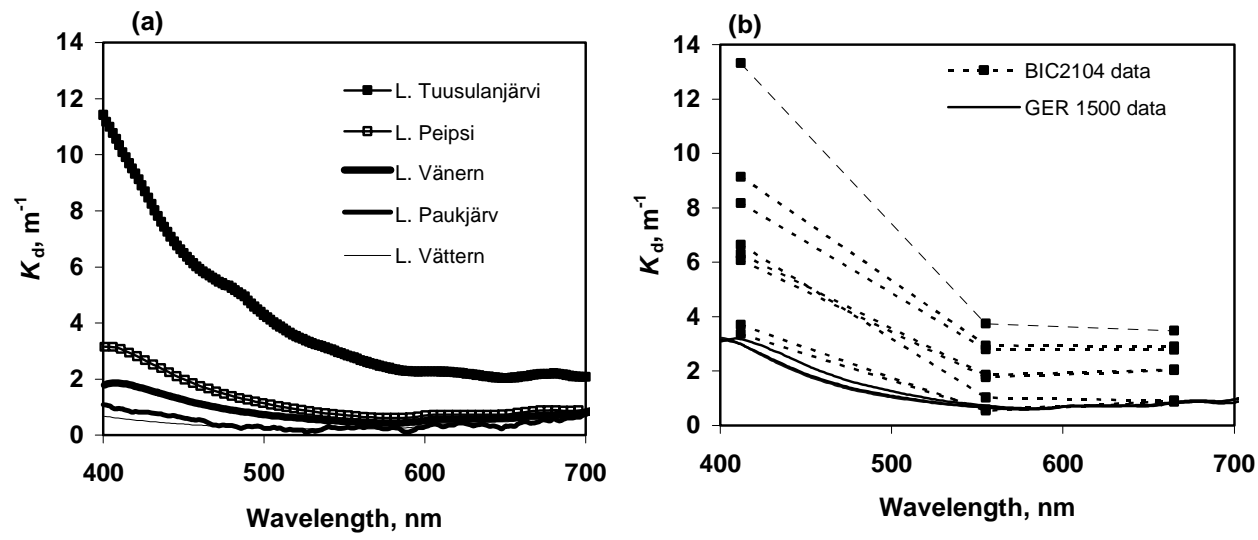

Fig. 5. Examples of diffuse attenuation coefficient spectra: (a) average measured in different lakes; (b) measured in different sampling stations in L. Peipsi by spectral and multispectral spectrometers.

$K_{\mathrm{d}}(\lambda)$ was measured only in the deepest part of the lake where OAS have the lowest concentrations $\left(C_{\text {chl }}=2.9-6.9 \mathrm{mg} \mathrm{m}^{-3}, \quad C_{\mathrm{SM}}=0.2-1.7 \mathrm{~g} \mathrm{~m}^{-3}, \quad\right.$ and $\left.a_{\mathrm{ys}}(380)=4.7-4.9 \mathrm{~m}^{-1}\right)$. Therefore they represent the lowest $K_{\mathrm{d}}$ values in this lake, being still notably higher than the average spectra from lakes Vättern, Vänern, and Paukjärv. Lake Paukjärv represents the lowest $K_{\mathrm{d}}$ values measured during the expeditions in Estonia and Finland in 1994-2000 (Fig. 5a). However, $K_{\mathrm{d}}$ values measured with a three-channel spectrometer BIC-2104 show that attenuation in shallow areas of a lake is sometimes comparable with most turbid samples measured earlier (e.g. L. Tuusulanjärvi) (Fig. 5b).

Detailed analysis of diffuse attenuation spectra in different types of lakes is presented by Reinart \& Herlevi (1999). In clear lakes (like L. Vättern) a small amount of CDOM causes an increase in the attenuation in the violet and blue parts of the spectrum, but the main attenuating factor in the red part of the spectrum is water itself. For these lakes it is characteristic that the highest attenuation is in the red part of the spectrum and that the irradiance that penetrates to the deepest layers is in the range $540-550 \mathrm{~nm}$. The values of $K_{\mathrm{d}}(\lambda)$ measured in the open area of L. Peipsi are comparable to the surface waters of L. Verevi, while in shallow areas of L. Peipsi they are similar to those in lakes Võrtsjärv and Ülemiste. In these shallow lakes rich in phytoplankton, the attenuation in the violet and blue parts of the spectrum typically exceeds the attenuation in the red part. An additional attenuation peak around $680 \mathrm{~nm}$, caused by absorption in phytoplankton pigments, is remarkable (even a weak maximum $\sim 620 \mathrm{~nm}$ could be seen). In these lakes irradiance is attenuated strongly over the whole spectrum, the most penetrating radiation being in the spectral range $590-650 \mathrm{~nm}$.

By our earlier measurements (Reinart \& Herlevi, 1999) the values of $K_{\text {d.PAR }}$ range from $0.3 \mathrm{~m}^{-1}$ in L. Paukjärv to $7.2 \mathrm{~m}^{-1}$ in Nohipalu Mustjärv. In L. Peipsi 
$K_{\text {d,PAR }}$ varied from 0.89 to $3.76 \mathrm{~m}^{-1}$, which means that the euphotic depth (the depth to which $1 \%$ of the subsurface irradiance reaches) varies there from 1.2 to $5.2 \mathrm{~m}$. As the mean depth of L. Peipsi is only $7 \mathrm{~m}$, large areas of bottom should be well lighted. This makes the light conditions in L. Peipsi very different from deep Swedish lakes, Vänern and Vättern, where PAR penetrates on average to depths of $5.7 \mathrm{~m}$ and $11.9 \mathrm{~m}$, the mean depth of lakes being 27 and $40 \mathrm{~m}$, respectively.

To understand the effect of the different configuration of the instrumentation to measurement results, $K_{\mathrm{d}, \mathrm{PAR}}$ data were plotted against $K_{\mathrm{d}}$ values at three wavelengths extracted from spectral $K_{\mathrm{d}}$, according to BIC-2104 bands 412, 555, and $665 \mathrm{~nm}$ (Fig. 6). There is a significant correlation between $K_{\mathrm{d}}$ at these three bands $\left(R^{2}=0.74-0.95\right)$. The $K_{\mathrm{d}, \mathrm{PAR}}$ values estimated from earlier spectral measurements in small Estonian and Finnish lakes gave the highest correlations with $K_{\mathrm{d}}(555)\left(R^{2}=0.67\right)$. This band is centred in the middle of the PAR region, and obviously is less affected by different OAS in water. Lower correlation coefficients were observed for bands 412 and $665 \mathrm{~nm}\left(R^{2}=0.58\right.$ and 0.57 , respectively). The BIC-2104 instrument gave quite similar results (see L. Peipsi measurements in Fig. 6) and despite the noteworthy scattering of points they are all in $95 \%$ limits estimated by previous measurements.

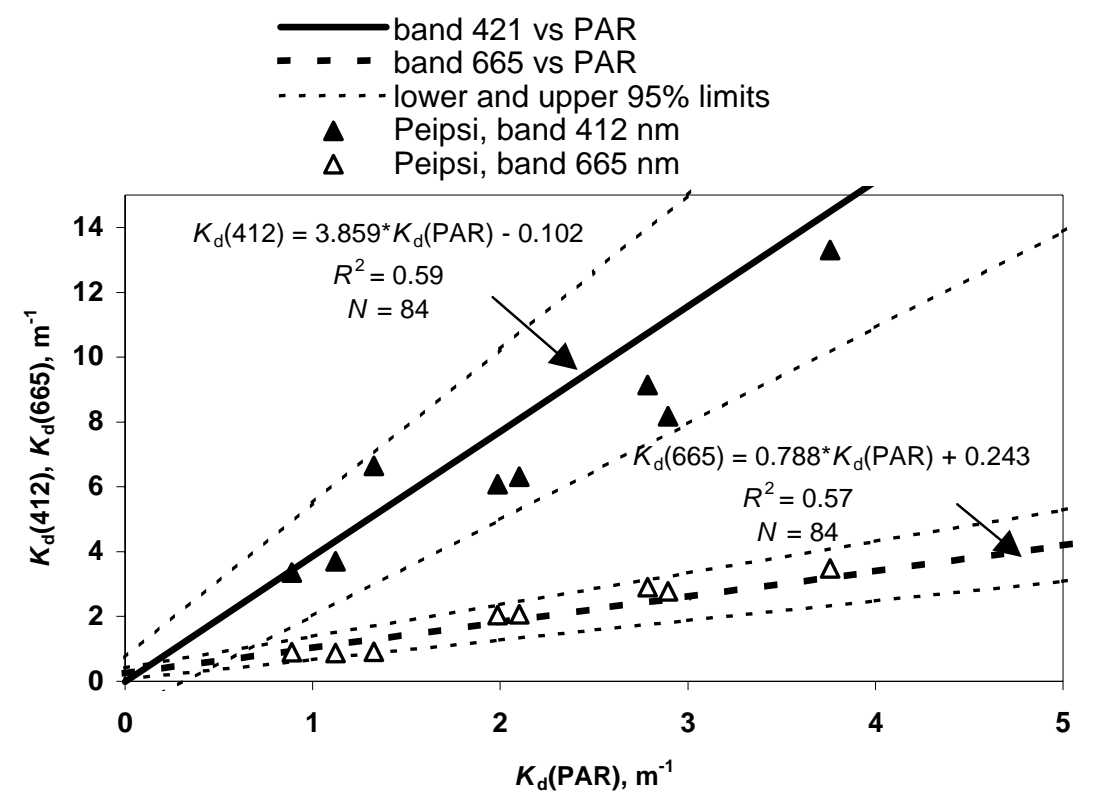

Fig. 6. Linear relationships of $K_{\mathrm{d}, \mathrm{PAR}}$ with $K_{\mathrm{d}}$ for bands centred at 412 and $665 \mathrm{~nm}$ (thin dotted lines show lower and upper limits of $95 \%$ confidence) and results from measurements in L. Peipsi (triangles). 


\section{Effect of coloured dissolved organic matter on the diffuse attenuation of downwelling irradiance}

A statistical analysis was performed using the spectral values of $K_{\mathrm{d}}$ and concentrations of OAS from Estonian and Finnish small lakes. The database was compiled during the years 1994-2000. The values of $C_{\text {chl }}$ varied from 1.28 to $87.33 \mathrm{mg} \mathrm{m}^{-3}, C_{\mathrm{MS}}$ was $0.5-20.80 \mathrm{~g} \mathrm{~m}^{-3}$, and $a_{\mathrm{ys}}(380) 0.68-14.24 \mathrm{~m}^{-1}$. The spectral distributions of the correlation coefficients between $K_{\mathrm{d}}$ and other water parameters are presented in Fig. 7. According to these results the main factor influencing the light attenuation in the violet and blue parts of the spectrum is yellow substance (at $400 \mathrm{~nm} R^{2}=0.897$ ). In the orange and red parts of the $K_{\mathrm{d}}$ spectra the correlation coefficient was highest for suspended particles containing chlorophyll $a$. Secchi depth is correlated negatively with spectral attenuation - its higher values correspond to lower attenuation, $R^{2}$ being $0.64-0.76$. These not very high values can be explained by simultaneous influence of many factors, including weather and sensitivity of human eyes.

To derive an empirical relationship between CDOM and $K_{\mathrm{d}}$ relying on BIC2104 data the earlier dataset was reviewed and from $K_{\mathrm{d}}$ spectra values according to three spectral bands of the BIC instrument were extracted. Best relationships with $a_{\mathrm{ys}}(380)$ were shown by $K_{\mathrm{d}}(412)$ and the ratio $K_{\mathrm{d}}(555) / K_{\mathrm{d}}(655)$ (Table 3 and Fig. 8). The respective errors in the values of $a_{\mathrm{ys}}(380)$ were 1.28 and $1.45 \mathrm{~m}^{-1}$. The non-zero intercept in the relationship using bands 555 and 665 shows that a significant part of the attenuation at these bands is caused by other OAS than CDOM.

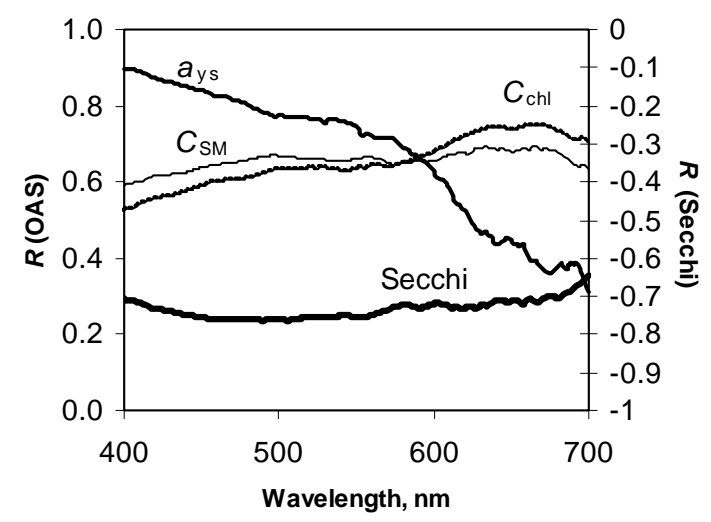

Fig. 7. Spectral distribution of correlation coefficient $R(p<0.05)$ between $K_{\mathrm{d}}(\lambda)$ and concentrations of optically active substances (left axis) and $K_{\mathrm{d}, \mathrm{PAR}}$ and Secchi depth (right axis). The wavelength interval for each curve is $5 \mathrm{~nm}$. 
Table 3. Determination coefficients $\left(R^{2}\right)$ for regression between the absorption coefficient of yellow substance $a_{\mathrm{ys}}(380)$ and $K_{\mathrm{d}}$ at three BIC bands

\begin{tabular}{lccc}
\hline & Band 412 & Band 555 & Band 665 \\
\hline$a_{\mathrm{ys}}(380)$ vs. $K_{\mathrm{d}}$ & 0.85 & 0.77 & 0.42 \\
$\ln \left[a_{\mathrm{ys}}(380)\right]$ vs. $\ln \left[K_{\mathrm{d}}\right]$ & 0.91 & 0.74 & 0.44 \\
& Ratio 412/665 & Ratio 412/555 & Ratio 555/665 \\
$a_{\mathrm{ys}}(380)$ vs. ratio & 0.61 & Insignificant & 0.89 \\
$\ln \left[a_{\mathrm{ys}}(380)\right]$ vs. $\ln [$ ratio $]$ & 0.75 & Insignificant & 0.83
\end{tabular}

Yellow substance is the most powerful light absorbing component in many Estonian lakes (Arst et al., 1997; Reinart et al., 2003) and also in lakes investigated by us in Finland and Sweden (Reinart et al., 2004). In Lake Peipsi 34-80\% of the attenuation of daylight in the blue region is caused by yellow substance. Its effect is comparable with absorption by pure water in the middle of the visible region (band centred at $555 \mathrm{~nm}$ ), where the absorption by CDOM is 13-39\%. The effect of CDOM is lowest in the $665 \mathrm{~nm}$ band (2-10\%). This large variability in every spectral region is caused by the large variation of OAS in L. Peipsi and shows that CDOM cannot be considered similarly over the whole aquatorium. In L. Vättern the influence of CDOM in the blue region of the spectrum is higher ( 90\%) than in L. Peipsi, because the concentration of other OAS is very small. In L. Vänern, where also the concentration of OAS is generally smaller than in L. Peipsi (Table 1), the effect caused by CDOM varies around $80 \%$ in the blue region and $36 \%$ in the green, being slightly higher than in L. Peipsi. On the basis of this limited number of samples the variation of the CDOM effect in L. Vänern and L. Vättern was not so large as in L. Peipsi.
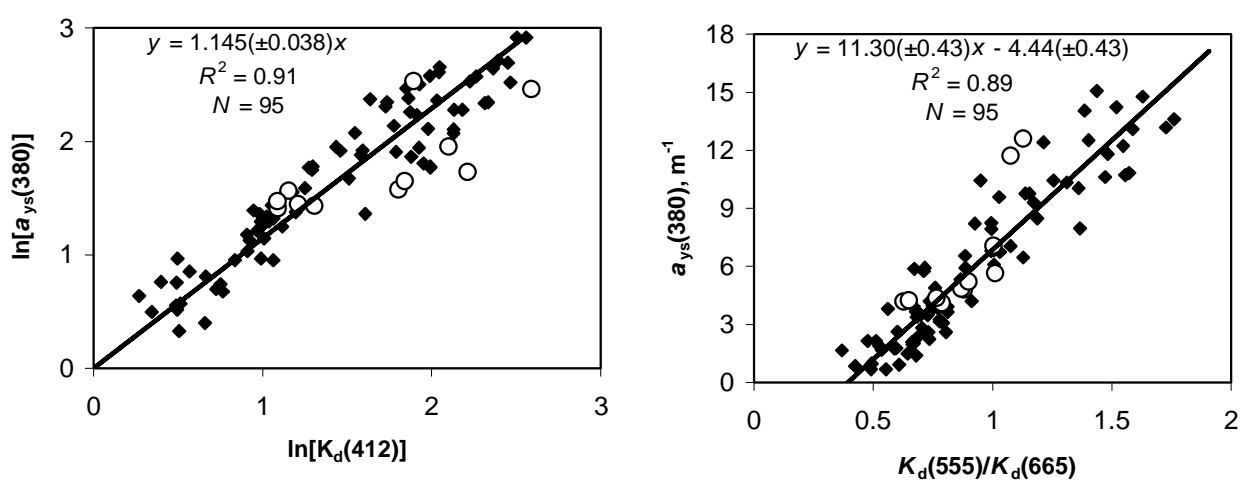

Fig. 8. Relationships between $a_{\mathrm{ys}}(380)$ and $K_{\mathrm{d}}$ values at BIC-2104 bands derived from spectral measurements in Estonian and Finnish lakes (filled squares) and data obtained for L. Peipsi in 2003 (open circles). 
The variations caused by spatial and seasonal variability of DOM and other substances in waters induce the different water types over the lake. In June the open area of the lake is mainly of "Moderate" type by the classification of small lakes (Reinart et al., 2003), while measurements in August showed very turbid water in the southern part of L. Peipsi s.s. and in L. Lämmijärv, and coastal waters probably belong even to "Brown" type.

The concentration and properties of allochthonous CDOM brought into the lake by rivers and from coastal soils depend very much on the annual water balance. The water level and its seasonal change in L. Peipsi are highly variable (difference more than $1.5 \mathrm{~m}$ ), the inflow to the lake is usually 5-6 times higher in April and May than in June, and very low around midsummer (Jaani \& Kullus, 2001). According to regular monitoring data (T. Nõges, pers. comm., 2004) in 2001-02 $a_{\mathrm{ys}}(380)$ showed an almost twofold variation $\left(5.0-7.9 \mathrm{~m}^{-1}\right.$ in the open area of the lake and 6.9-12.6 $\mathrm{m}^{-1}$ close to the Suur-Emajõgi River inflow). However, for the open area the highest values of CDOM are measured in June, but in the river mouth in November (in 2001) or August (in 2002). Even these values may be slightly higher than were obtained in the present study (because no correction for residual scattering was applied), they still show large spatial and temporal variability due to the complexity of problems related to the effect of DOM to the light climate in L. Peipsi. This points out the need for more extensive and detailed investigations.

\section{CONCLUSIONS}

Results obtained by in situ measurements and analysis of water samples in 16 sampling stations in Lake Peipsi in June, August, and November 2003 describe the variability of light attenuation in water as well as the influence of dissolved organic matter on the underwater light field in a large, seasonally changeable lake.

The beam absorption coefficient of filtered water at $380 \mathrm{~nm}$ varied from 4.1 to $16.7 \mathrm{~m}^{-1}$. In general there was no direct connection between the distance from the mouth of the Suur-Emajõgi River and the concentration of coloured dissolved organic matter, but its highest values were observed in the area of the river inflow. All water samples taken from L. Lämmijärv and closer than $1.9 \mathrm{~km}$ to the coast of L. Peipsi gave the values of $a_{\mathrm{ys}}(380)$ higher than its average over the Estonian and Finnish lakes studied earlier. The amount of CDOM in L. Peipsi is also much higher than in two other large European lakes, Vänern and Vättern in Sweden.

In L. Peipsi the slope factor $S(380-550)$ varied from 0.015 to $0.018 \mathrm{~nm}^{-1}$ when GF/F filters were used, and in the range $0.016-0.019 \mathrm{~nm}^{-1}$ in the case of filters with pore size $0.2 \mu \mathrm{m}$. These values are within the range obtained by us and other authors for small lakes, but slightly higher than we estimated in large Swedish lakes.

Comparison of the results obtained using filters with pore size 0.6-0.7 (GF/F) and $0.2 \mu \mathrm{m}$ (102 water samples from various types of lakes in Estonia, Finland, 
and Sweden were analysed) showed that two datasets of $a_{\mathrm{ys}}(380)$ had very high determination coefficients $\left(R^{2}=0.993\right)$. Using smaller pore size filters we got on average $4 \%$ lower absorption values. When $a_{\mathrm{ys}}(380)$ was more than $8 \mathrm{~m}^{-1}$, the effect of smaller pore size was less than $4 \%$. The respective values of the slope factor $S(380-550)$ had lower values of $R^{2}(0.49)$, and an increase of about $10 \%$ was observed in the slope. This needs to be taken into account when different datasets are merged.

In L. Peipsi yellow substance causes $34-80 \%$ of the attenuation of daylight in the blue region of the spectrum. CDOM absorption constitutes $13-39 \%$ of the attenuation in the middle of the visible region, and its effect there is comparable with the absorption by pure water.

The measurement results of the diffuse attenuation coefficient carried out by new instrumentation (BIC-2104) are highly consistent with our earlier data (spectral measurements using a spectrophotometer LI-1800UW) in Estonian and Finnish lakes. The values of $a_{\mathrm{ys}}(380)$ can be predicted by the logarithmic relationship with $K_{\mathrm{d}}$ at $412 \mathrm{~nm}$ or the ratio of $K_{\mathrm{d}}(555)$ to $K_{\mathrm{d}}(665)$ (the standard error is 1.3 and $1.5 \mathrm{~m}^{-1}$, respectively). For a more profound description of spatial and seasonal variation in bio-optical parameters (including CDOM) over L. Peipsi complex optical and hydro-meteorological investigations are needed.

\section{ACKNOWLEDGEMENTS}

This study was supported by EU Marie Curie Fellowship, contract No HPMFCT-2001-01284, Swedish National Space Board grant 132/03, and Estonian Science Foundation grant 5738. We acknowledge the Estonian Maritime Administration for providing a boat for the field survey and financial co-support from the European Commissions's Environment and Sustainable Development Programme under contract EVK1-CT-2002-00121 (CLIME). Additional data obtained in the frames of the State Monitoring Programme of the Estonian Ministry of the Environment were used.

\section{REFERENCES}

Aas, E. 2000. Spectral slope of yellow substance: problems caused by small particles. In Proc. XV Conference of Ocean Optics, Monaco, p. 8 (CD-ROM).

Arst, H. 2003. Optical Properties and Remote Sensing of Multicomponental Water Bodies. Springer, Praxis Publishing, Chichester, UK.

Arst, H., Mäekivi, S., Lukk, T. \& Herlevi, A. 1997. Calculating irradiance penetration into water bodies from the measured beam attenuation coefficient. Limnol. Oceanogr., 42(20), 379-385.

Arst, H., Erm, A., Kallaste, K., Mäekivi, S., Reinart, A., Nõges, P. \& Nõges, T. 1999. Investigation of Estonian and Finnish lakes by optical measurements in 1992-1997. Proc. Estonian Acad. Sci. Biol. Ecol., 48, 5-24.

Bricaud, A., Morel, A. \& Prieur, L. 1981. Absorption by dissolved organic matter in the sea (yellow substance) in the UV and visible domain. Limnol. Oceanogr., 26, 43-53. 
Cole, J. J., Caraco, N. F., Kling, G. W. \& Kratz, T. K. 1994. Carbon dioxide supersaturation in the surface waters of lakes. Science, 265, 1568-1570.

Davies-Colley, R. J. \& Vant, W. N. 1987. Absorption of light by yellow substance in freshwater lakes. Limnol. Oceanogr., 32, 416-425.

Dera, J. 1992. Marine Physics. PWN, Warszawa and Elsevier, Amsterdam.

Duarte, C. M. 1991. Seagrass depth limits. Aquat. Bot., 40, 363-377.

Fedorov, K. N. \& Ginsburg, A. I. 1992. The Near-Surface Layer of the Ocean. VSP, Utrecht, The Netherlands.

Freeman, C., Evans, C. D., Monteith, D. T., Reynolds, B. \& Fenner, N. 2001. Export of organic carbon from peat soils. Nature, $\mathbf{4 1 2}, 785$.

Gallie, E. A. 1994. Optical calibration parameters for water-color models from Swan lake, Northern Ontario. Can. J. Remote Sensing, 20,156-161.

Gege, P. 2000. Gaussian model for yellow substance absorption spectra. In Proc. XV Conference of Ocean Optics, Monaco, p. 9 (CD-ROM).

Herlevi, A., Virta, H., Arst, H. \& Erm, A. 1999. Results of light absorption/attenuation measurements in Finnish and Estonian lakes in summer 1997. Proc. Estonian Acad. Sci. Biol. Ecol., 48, 46-62.

Hoge, F. E., Vodacek, A. \& Blough, N. V. 1993. Inherent optical properties of the ocean: retrieval of the absorption coefficient of chromophoric dissolved organic matter from fluorescence measurements. Limnol. Oceanogr., 38, 1394-1402.

Jaani, A. \& Kullus, L.-P. 2001. Hydrological regime and water balance. In Lake Peipsi. Meteorology, Hydrology, Hydrochemistry (Nõges, T., ed.), pp. 65-72. Sulemees, Tartu.

Jansson, M. 1998. Nutrient limitation and bacteria-phytoplankton interactions in humic lakes. In Aquatic Humic Substances: Ecology and Biogeochemistry (Hessen, D. O. \& Tranvik, L. J., eds.), pp. 177-195. Ecol. Stud., 133. Springer Verlag.

Kallio, K. 1999. Absorption properties of dissolved organic matter in Finnish lakes. Proc. Estonian Acad. Sci. Biol. Ecol., 48, 75-83.

Krause-Jensen, D. \& Sand-Jensen, K. 1998. Light attenuation and photosynthesis of aquatic plant communities. Limnol. Oceanogr., 43, 396-407.

Kirk, J. T. O. 1994. Light and Photosynthesis in Aquatic Ecosystems. Cambridge University Press.

Lindell, T., Pierson, D., Premazzi, G. \& Ziliolli, E. 1999. Manual for Monitoring European Lakes Using Remote Sensing Techniques. Office for Official Publications of the European Communities, Luxembourg.

Mäekivi, S. \& Arst, H. 1996. Estimation of the concentration of yellow substance in natural waters by beam attenuation coefficient spectra. Proc. Estonian Acad. Sci. Ecol., 6, 108-123.

Miller, L. W., Johannessen, S. \& Kuhn, P. 2000. The optical properties of dissolved organic matter (DOM) in coastal and open waters. In Proc. XI Conference of Ocean Optics, Monaco, p. 6 (CD-ROM).

Mobley, C. D. 1994. Light in Water-Radiative Transfer in Natural Waters. Academic Press, San Diego. Nõges, T. (ed.) 2001. Lake Peipsi. Meteorology, Hydrology, Hydrochemistry. Sulemees, Tartu.

Östlund, C., Flink, P., Strömbeck, N., Pierson, D. \& Lindell, T. 2001. Mapping of the water quality of Lake Erken, Sweden from Imaging Spectrometer and Landsat Thematic Mapper. Sci. Total Environ., 268, 139-164.

Pierson, D. C. \& Strömbeck, N. 2001. Estimation of radiance reflectance and the concentrations of optically active substances in Lake Mälaren, Sweden, based on direct and inverse solutions of a simple model. Sci. Total Environ., 268, 171-188.

Pope, M. \& Fry, E. S. 1997. Absorption spectrum (380-700 nm) of pure water. II. Integrating cavity measurements. Appl. Optics, 36, 8710-8723.

Reinart, A. \& Herlevi, A. 1999. Diffuse attenuation coefficient in some Estonian and Finnish lakes. Proc. Estonian Acad. Sci. Biol. Ecol., 48, 267-283.

Reinart, A., Herlevi, A., Arst, H. \& Sipelgas, L. 2003. Preliminary optical classification of lakes and coastal waters in Estonia and South-Finland. J. Sea Res., 49, 357-366. 
Reinart, A., Paavel, B. \& Pierson, D. 2004 Comparison of optical properties of three large European lakes. Boreal Envir. Res. (submitted).

Schanz, F. 1985. Vertical light attenuation and phytoplankton development in Lake Zürich. Limnol. Oceanogr., 30, 299-310.

Sipelgas, L., Kallio, K., Arst, H., Erm, A., Oja, P. \& Soomere, T. 2003. Optical properties of dissolved organic matter in Finnish and Estonian lakes. Nord. Hydrol., 34, 361-386.

Sobek, S., Algesten, G., Bergström, A.-K., Jansson, M. \& Tranvik, L. 2003. The catchment and climate regulation of pCO2 in boreal lakes. Global Change Biol., 9, 630-641.

Strömbeck, N. 2001. Water quality and optical properties of Swedish lakes and coastal waters in relation to remote sensing. Comprehensive Summaries of Uppsala Dissertations from Faculty of Science and Technology, 633. Uppsala.

Strömbeck, N. \& Pierson, D. 2001. The effects of variability in the inherent optical properties on the estimations of the chlorophyll-a by remote sensing in Swedish freshwaters. Sci. Total Environ., 268, 123-137.

Virta, J. \& Blanco-Sequeiros, A. 1995. Correction of measured underwater spectral irradiance to the variation of some external effects with examples. Rep. Ser. in Geophys. University of Helsinki (Pukkinen, K., ed.), 32, 93-100.

\title{
Vees lahustunud orgaanilise aine mõju valguse nõrgenemisele Peipsi järves
}

\author{
Anu Reinart, Birgot Paavel ja Lea Tuvikene
}

Käesolevas töös on uuritud vees lahustunud värvunud orgaanilise aine (CDOM) mõju Peipsi järve veealusele valgusväljale veesiseste kiirgusmõõtmiste ja veeproovide analüüside kaudu. Tulemusi on võrreldud suurte järvede Vänerni ja Vätterniga (Rootsi) ja 41 väikejärvega Eestis, Soomes ja Rootsis. CDOM-i hulk kaldast kuni kauguseni $1,9 \mathrm{~km}$ on suurem $\left(a_{\mathrm{ys}}(380)=7,1-16,7 \mathrm{~m}^{-1}\right)$ kui avajärve mõõtepunktides $\left(a_{\mathrm{ys}}(380)=4,1-5,6 \mathrm{~m}^{-1}\right)$. Otsest seost CDOM-i kontsentratsiooni ja kauguse vahel Suure-Emajõe suudmest ei leitud. Peipsi järvele on iseloomulik suur ajaline ja ruumiline CDOM-i hulga varieeruvus, kuid see jääb siiski samadesse piiridesse, kui varem uuritud Eesti ja Soome väikejärvedes. Peipsi vesi sisaldab keskmiselt 2 korda rohkem lahustunud orgaanilist ainet kui Vänern ja 7 korda rohkem kui Vättern. Vee optiline tüüp Peipsi järves varieerub sõltuvalt piirkonnast. CDOM-i hulka vees on iseloomustatud filtreeritud vee neeldumiskoefitsiendi järgi fikseeritud lainepikkusel ja neeldumise eksponentsiaalset vähenemist lainepikkusega kirjeldatava nn tõusu parameetriga. On uuritud sageli kasutatavate erineva poorisuurusega filtrite mõju neile tulemustele $(0,6-0,7 \mu \mathrm{m}$ ja $0,2 \mu \mathrm{m})$. Osutub, et kahel viisil mõõdetuna korreleerusid CDOM-i hulga väärtused omavahel väga hästi $\left(R^{2}=0,99\right)$, kuid tõusu parameetrid vähem $\left(R^{2}=0,49\right)$. Varem kogutud spektraalse vertikaalse nõrgenemiskoefitsiendi andmebaasi ja uue, 3-kanalilise spektromeetri mõõtmiste võrdlemine andis kooskõlalised tulemused. Leitud on ka esialgsed empiirilised seosed CDOM-i ja kiirguse nõrgenemiskoefitsiendi vahel Peipsi järve jaoks. Täpsemaid seoseid ning CDOM-i ruumilist ja ajalist varieeruvust Peipsi järve akvatooriumis tuleks aga edaspidi uurida kooskõlas teiste hüdrometeoroloogiliste faktoritega. 